\title{
MEDIA MONITORING MODEL IN PUBLIC RELATIONS OF BUMN (State-owned enterprises) COMPANIES
}

\author{
Oktaria Sukmayani, Jamroji \\ University of Muhammadiyah Malang, Indonesia \\ Oktari70@gmail.com, jamroji@umm.ac.id
}

Received: 09-03-2021 Revised: 06-05-2021 Accepted: 28-07-2021

\begin{abstract}
Media monitoring is a form of Public Relations activity used in many companies, including the companies in Indonesia, to monitor mass media coverage and to find out current issues among the public. One of the companies that implement media monitoring activities in PT Perkebunan Nusantara (PTPN) X. PTPN X is a state-owned company engaged in the sugar and tobacco business in Indonesia. The purpose of this study is to describe the monitoring media model in the Public Relations of BUMN companies, namely PT Perkebunan Nusantara X Surabaya. In this study, the researcher used a qualitative descriptive approach through data collection by observation, interviews, and documentation. The theory used was the theory of Evaluation of Public Relations. One form of Evaluation of Public Relations is media monitoring. The results of this study found that the media monitoring model applied by PTPN X was a media monitoring model in normal conditions and the model during a crisis. This research is indispensable in the development of media monitoring practices and studies in Indonesia, especially for the Public Relations/Public Relations department.
\end{abstract}

Keywords: Media Monitoring, Public Relations, Evaluation Public Relations.

\begin{abstract}
Abstrak
Media monitoring merupakan salah satu bentuk kegiatan Humas yang digunakan di banyak perusahaan, termasuk perusahaan-perusabaan di Indonesia, untuk memantau pemberitaan media massa dan untuk mengetabui isu-isu terkini di masyarakat. Salah satu perusahaan yang melaksanakan kegiatan media monitoring di PT Perkebunan Nusantara (PTPN) X. PTPN X merupakan perusabaan milik negara yang bergerak di bidang usaha gula dan tembakau di Indonesia. Tujuan dari penelitian ini adalah untuk mendeskripsikan model media monitoring pada Humas perusabaan BUMN yaitu PT Perkebunan Nusantara X Surabaya. Dalam penelitian ini, peneliti menggunakan pendekatan deskriptif kualitatif melalui pengumpulan data dengan observasi, wawancara, dan dokumentasi. Teori yang digunakan adalab teori Evaluasi Public Relations. Salah satu bentuk Evaluasi Humas adalah media monitoring. Hasil penelitian ini menemukan bahwa model media monitoring yang diterapkan PTPN X adalab model media monitoring pada kondisi normal dan model pada saat krisis. Penelitian ini sangat diperlukan dalam pengembangan praktik. dan kajian media monitoring di Indonesia, khususnya bagi jurusan Humas/Humas.
\end{abstract}

Kata Kunci: Media Monitoring, Humas, Evaluasi Humas 


\section{INTRODUCTION}

The development of a company cannot be separated from the contributions of various parties. A company will be able to develop properly if there is an understanding between the company and the various existing stakeholders. To reach this understanding, good corporate governance is needed through an effective communication process or there is reciprocity between the company and its audiences, both internal and external audiences. Kriyantono (2014), argues that communication is the main tool of Public Relations which plays a central role in the process of interconnection between organizations, PR, and the public. ${ }^{1}$

The involvement of the Public Relations (PR) department in an organization/company management can be said to play an important role, apart from having a strategic position, PR also regulates the course of communication and dissemination of information with the public. Public relations must be the eyes, ears, feet, and hands of the company to listen to what is happening and what the audience wants as well as a bridge between the audience and the company.

The success of the Public Relations/Public Relations department is determined by several factors, one of which is the presence of positive publicity about the company in the mass media. Lesly (2003), states that publicity is the planned distribution of information/messages using certain media, to achieve organizational interests without making payments to the media. ${ }^{2}$ In this case, the mass media has a big share in the process of conveying information to the public, and for the success of activities carried out by PR to build a good reputation for the company. The mass media has the task of controlling/monitoring, the task of educating, the task of entertaining, and the task of influencing. Mass media can influence the public both positively, for example, to build a good image of individuals, organizations/companies, and the nation as well as negative ones, for example, to build negative public opinion through the news. ${ }^{3}$ This negative public opinion needs to be watched out for by the company, especially by the Public Relations / Public Relations department because it will affect the image and reputation of the company. Therefore, Public Relations must have a good strategy to control mass media coverage, one of which is through a media monitoring activity.

Media monitoring is a method used to evaluate PR programs and usually takes the form of newspaper clippings, transcripts, or recordings of electronic media broadcasts. This data shows how much coverage has been achieved, and the type usually emphasizes quantitative evaluation and does not indicate the achievement of quality coverage. ${ }^{4}$ Media monitoring is also defined as the evaluation stage of media relations and is more directed at

\footnotetext{
${ }^{1}$ Rachmat Kriyantono, 'Peran Manajerial Dan Teknisi Humas Lembaga Pemerintah Dan Swasta', Aristo, 6.1 (2018), $1<$ https://doi.org/10.24269/ars.v6i1.760>. 84.

${ }^{2}$ Nunung Prajarto, 'Efektivitas Publisitas: Menilai Reputasi Institusi', Jurnal Ilmu Komunikasi, 6.2 (2008), 78-

${ }^{3}$ Darmastuti, Rini.Media Relations:Konsep, Strategi \& Aplikasi.Yogyakarta:ANDI OFFSET,2012.

${ }^{4}$ Prayudi.Penulisan Naskah Public Relations.Yogyakarta:ANDI OFFSET,2007.
} 
the output produced by the mass media or feedback from the mass media. ${ }^{5}$ Meanwhile, news monitoring work/media monitoring is part of PR activities to determine the dynamics of the external environment. Monitoring the dynamics of the external environment is the first step in any business strategy, not just a PR strategy. PR practitioners play an important role in it. This step is also often referred to as observation. ${ }^{6}$ If there is a problem in the news during the media monitoring process at the Bureau of the Ministry of Trade of the Republic Indonesia, both in the form of errors in writing quotations from sources or news that spread are not following the facts, the Bureau of the Ministry of Trade of the Republic Indonesia uses a method/strategy by issuing a press release as the right of responsibility for the news crisis. ${ }^{7}$ PR is not only monitoring offline and online media, but also social media. Social media is currently the most widely used media, most-liked and trusted by the public. ${ }^{8}$

One of the companies that implement media monitoring activities in PT Perkebunan Nusantara (PTPN) X. PTPN X is an agribusiness company based on state-owned plantations. The main businesses being developed are sugar and tobacco. Meanwhile, other business units being developed include Cutting Bobbin, Hospital, Bioethanol, Edamame, Plastic, Inner bag, and Waring services. PTPN X has nine sugar factories (PG Kremboong, PG Gempolkrep, PG Djombang Baru, PG Tjoekir, PG Lestari, PG Meritjan, PG Pesantren Baru, PG Ngadirejo, PG Modjopanggoong) and three tobacco gardens (Kebun Ajung Gayasan, Kertosari, and Kebun Kebonarum / Gayamprit / Wedhibirit) spread across East Java and Central Java. ${ }^{9}$

At PTPN X, media monitoring activities are carried out every day during working hours, by monitoring news in printed media (newspapers) and online media (news portals) by reading all news content in newspapers and searching for news on search engines such as Google for online media. There are six types of newspapers used and subscribed to in monitoring media activities by Public Relations of PTPN X including Jawa Pos, Kompas, Bisnis Indonesia, Radar Surabaya, Surya, and Memorandum.

The importance of discussing media monitoring further is to monitor and hear public opinion and measure how much publicity the mass media has done to the company, whether the mass media reports the company in a positive, neutral or negative tone. With this, PR will be able to prepare and compile strategic steps based on the analysis that has been carried out in monitoring media activities. On the other hand, this media monitoring activity is also a step to minimize the occurrence of a bigger impact/risk leading to a crisis. Public relations must first manage the issue so that it does not develop into a crisis. Issue management is carried out as a precautionary step before a crisis occurs and must also be done when a crisis is ongoing.

5 Aditya Ilham Gunawan and Renata Anisa, 'Kegiatan Media Monitoring Humas Pemerintah Kota Cimahi', Ekspresi Dan Persepsi : Jurnal Ilmu Komunikasi, 3.2 (2020), 122 <https://doi.org/10.33822/jep.v3i2.1758>.

${ }_{6}$ Makmur, Riniwaty.Media Relations di Balik Layar:Praktik, Tips dan Teori.Jakarta:PT Kompas Media Nusantara, 2019.

7 Mia Rizqi Maulida and Tresna Wiwitan, 'Aktivitas Media Monitoring Biro Humas Kementerian Perdagangan Republik Indonesia', 164-69.

8 Arief, Nurlaela.Public Relations In The Era of Artificial Intelligence: Bagaimana Big Data dan AI Merevolusi Dunia PR.Bandung:Simbiosa Rekatama Media, 2019.

9 ptpn10.co.id.(2021, 24 Februari). Sejarah Perusahaan. Diakses pada 24 Februari 2021, dari http://ptpn10.co.id/page/profil\#sejarah 
Therefore, the researcher is interested in discussing the media monitoring model applied by the Public Relations of BUMN companies (study at PT Perkebunan Nusantara X). The researcher assumes that the monitoring media model applied by the company has different handling in a certain situation both under normal circumstances and when the company is in trouble.

\section{RESEARCH METHOD}

In this study, the researcher used a descriptive qualitative approach based on case study research and data collection methods, namely observation, interviews, and documentation. A qualitative approach is a research that is aimed to describe and analyze phenomena, events, social activities, attitudes, individual or groups thought. ${ }^{10}$ The researcher used this research approach to describe the Media Monitoring Model in Public Relations of State-Owned Enterprises (Study on Public Relations of PT Perkebunan Nusantara X). A case study is a research design that includes an intensive study of a research unit. Although the number of subjects tends to be small, the variables studied are very broad. Therefore, the researcher must know all the variables associated with the problem under study. ${ }^{11}$

In this study, researchers used primary data sources, namely observation, and interviews. Observations were carried out for six months in February - August 2019, the researcher observed daily activities, especially regarding monitoring media carried out by the Public Relations of PTPN X. While documentation is supporting data in the form of news scripts in mass media monitored by Public Relations of PTPN X during the period 4 February - 5 August 2019 which was then analyzed based on Jim Macnamara's theory of news content analysis.

\section{DISCUSSION}

\section{Media Monitoring Process at PT Perkebunan Nusantara X}

The process carried out for monitoring activities of printed media (newspaper) and online media (news portal) is divided into several stages which are planning, implementation, and evaluation stages.

\section{Planning}

At the planning stage, PTPN X Public Relations first selects the type of media to be monitored. The type of media used is printed media and online media. Printed media consists of six types of newspapers that are monitored, such as Jawa Pos, Kompas, Bisnis Indonesia, Radar Surabaya, Surya, and Memorandum. The six types of newspapers are PTPN X subscribed newspapers. Meanwhile, for online media, there is no media limit, which means that all news portals reporting about PTPN X are included in the monitoring of PTPN X's media. After selecting the type of media to be monitored and analyzed, the next step is to determine the format of the monitoring media report. The media monitoring report format of PT Perkebunan Nusantara X consists of several parts, cover page, and the next page contains a column regarding the name of the media reporting, the date of publication, the page/link,

10 Machmud, Muslimin.Tuntutan Penulisan Tugas Akhir Berdasarkan Prinsip Dasar Penelitian Ilmiah.Malang:Penerbit Selaras, 2016.

${ }^{11}$ Ibid. 
the spectrum of media publication coverage, news sentiment/tone and the name of the news reporter. Then below the column contains scanned news snippets (especially newspapers) and news screenshots for online media.

\section{Implementation}

The implementation stage of media monitoring at PTPN X starts from looking and reading the news headlines first in the main news section of each print media. After that, then continue to the next page to look for other news related to the company by holding the keywords PTPN X (including sugar factories, tobacco plantations, and other business ventures owned by PTPN X), holding PTPN III, BUMN institutions, the development of sugar, sugar cane and tobacco and others related to PTPN X every day during working hours. Second, collecting and separating data, if there is a news headline in the printed media that includes the name of the company PTPN X and PTPN Holding, regarding the development of sugar, sugar cane, and tobacco, the separation process, and data collection is carried out, by cutting/clipping related news and writing the name of the media, published date, page, name of journalist/writer and editor on the back of the cut newspaper. Third, conduct content analysis by reading the entire news content or each paragraph starting from the news headlines, news title, news headlines, news bodies, and news tails. Fourth, provide an assessment of news sentiment/tone. There are three types of news sentiment/tone those are positive, neutral, and negative. Fifth, compiling media monitoring reports. The PTPN X media monitoring report framework contains a report cover, consisting of the title, "Media Monitoring Report", the PTPN X company logo, and the date. While online media monitoring activities are carried out not much different from printed media, it's just that the news search process is slightly different from printed media, by entering keywords in a search engine such as Google. After that, look at the news headlines that are presented, and don't forget to see the publication date of each news available on the Google search engine. If there is news about PTPN X on the online media news portal, then a screenshot of the related news is carried out and put in the media monitoring report of PTPN X. The online media monitoring report format is the same as the printed media, but what distinguishes it is the page column containing the news portal website address.

\section{Evaluasi}

In the evaluation stage, the monitoring media reports that have been compiled and analyzed by the Public Relations of PTPN X are then reported to the Board of Management and the company secretary. If the sentiment is in the form of negative sentiment, it will be immediately discussed together with the head of the company secretary department, then confirm it to the Board of Management and take certain steps. Also in this process, the results of the analysis of news content are used as consideration in making policies on related issues.

Based on the explanation above, the media monitoring process at PTPN X can be said to be in the industry level 1.0 and 2.0 collaboration, where the collaboration between printed media and online media (news portals) as a source of information is applied by Public Relations of PTPN X in the process of external monitoring media. The work of monitoring the print media (newspapers) at PTPN X is still carried out traditionally, manually monitoring the media by reading the newspaper every day. PR 1.0 is a period where PR professionals or practitioners are described as broadcasters, that is, the form of communication that occurs is 
one-way or vertical from one source of communication to many audiences. During this period PR carried monitors manually. Sources of information are printed media such as newspapers, magazines, television. ${ }^{12}$

Second, the PR of PTPN X is seen utilizing online media (news portals) as a medium to obtain information in monitoring media activities. Not a few printed media (newspapers) have a news portal website to publish their news. This is because the newspaper has a very limited position when it comes to publishing all received news, so the printed media publish it on the news portal website of each media. Public Relations of PTPN X then responsively utilized online media (news portals) for monitoring. This is in line with PR 2.0, PR is described as a connector, which is a form of communication that is horizontal, interconnected, communication from many sources to many audiences. At this time it is considered as the birth of online media. A lot of online media have sprung up until the transformation of printed media has moved to digital platforms. ${ }^{13}$

While at the industry level 3.0 and 4.0, PTPN X Public Relations has not carried out monitoring media on social media and has not made use of various Artificial Intelligence (AI) application products that support media monitoring activities at PTPN X. Social media is only used as a medium to disseminate information about company activities as well as related to untrue news about the company through a post on the Instagram account of PTPN X. In this case, the PR of PTPN X is seen only as a broadcaster and has not analyzed the calculation of engagement. On the other hand, the industry level 4.0 is only visible in the process of distributing releases to the media through the use of the Whatsapp application and via email.

As explained by PR 3.0, PR is not only monitoring online and offline media, but also social media. Meanwhile, PR 4.0 is an era in which artificial intelligence (AI) and big data are present. During this period, many tools can be utilized to simplify PR tasks. Activities such as dissemination of releases to various media, managing company campaigns, tools for identifying buzzers, influencers, and managing stakeholder data. In addition, managing platforms for digital, audio, and video content as well as analytic data management can be done with AI technology. ${ }^{14}$

When viewed from the planning, implementation, and evaluation processes of PTPN X's media monitoring activities, it can be seen that PTPN X's PR is carrying out the role of manager and communication technician. The manager is to carry out the functions and stages, which are planning, implementation (organizing, communicating, supervising), and scoring (evaluating). ${ }^{15}$ Meanwhile, the communication technician was seen when the Public Relations of PTPN X implemented a comprehensive management communication strategy by writing, editing, and documenting the monitoring media which were compiled in the PTPN X media monitoring report.

12 Arief, Nurlaela. Public Relations In The Era of Artificial Intelligence: Bagaimana Big Data dan AI Merevolusi Dunia PR.Bandung:Simbiosa Rekatama Media, 2019.

13 Ibid.

${ }^{14}$ Ibid.

15 Ruslan, Rosady. Manajemen Public Relations \& Media Komunikasi:Konsep dan Aplikasi.Jakarta:Rajawali Pers, 2012. 


\section{Media Monitoring in Normal Circumstances (A Developing Issue)}

PR Monitoring of developing issues is one of the activities carried out by the Public Relations staff of PTPN X to find information on potential issues currently being discussed by the public. In this process, it can be said to be a process of fact-finding on trending issues in the community. Monitoring potential issues will make it easier to define company problems, what are the strengths, weaknesses, opportunities, and threats for the company that will have an impact on the company's image and reputation. In organizational management, the role of PR is to evaluate public attitudes or opinions; identify policies \& procedures of the organization/company with its public interest; plan and implement public relations/PR activities. ${ }^{16}$ While Harrison (2008), Gaunt \& Ollenburger (1995), Jaquest (2010), Kouzmin (2008), Miller (1998), Regester \& Larkin (2008), Seitel (2001) suggest organizations should be proactive in monitoring and identifying issues. The process of identifying issues can be done by monitoring external public opinion, by monitoring mass media coverage. ${ }^{17}$

Dozier \& Broom (1995), divides the role of public relations into four: 1) Expert advisor (Expert prescriber), the PR helps provide advice and find solutions in solving problems related to relations with the public (public relationship). 2) Communication facilitator, PR serving as a communicator as well as a mediator to assist the management in hearing what the public wants and hopes are. 3) Facilitator of Problem Solving Process, PR is part of the management team, because it helps in the problem-solving process of public relations. PR helps organizational leaders as advisors and takes action (decisions) in dealing with problems or crises that are being faced nationally and professionally. 4) Communication Technician, makes PR as an in-resident journalist who provides technical communication services or commonly known with the method of communication in the organization. ${ }^{18}$

PT Perkebunan Nusantara X carries out activities in the form of subscribing to newspapers such as Jawa Pos, Bisnis Indonesia, Radar Surabaya, Surya, and Memorandum to find information about the company is a way to define problems as part of the PR process in solving problems and to assist management. PTPN X Public Relations then made observations by reading, analyzing, and reporting to the company secretary and management regarding the results of media monitoring activities. In this case, the Public Relations of PTPN X also plays a role as a communication facilitator and mediator, by carrying out twoway communication with the public through the mass media, then conveying public opinion about the company to the management and company secretaries. On the other hand, the PR of PTPN X also acts as an expert prescriber (expert advisor), which is to recommend several things regarding public affairs, both regarding the process and dissemination of information as well as contact with the mass media to superiors. Public Relations of PTPN X also takes direct execution if there are problems while monitoring the issue by issuing a press release together with the company secretary if there is a problem with the public.

${ }^{16}$ Ibid.

17 Kriyantono, Rachmad.Public Relations, Issue, \& Crisis Management:Pendekatan Critical Public Relations, Etnografi Kritis, \& Kualitatif:Mengenal Krisis: Jakarta:PRENANDAMEDIA GROUP, 2015.

18 Ruslan, Rosady. Manajemen Public Relations \& Media Komunikasi:Konsep dan Aplikasi.Jakarta:Rajawali Pers, 2012. 
In monitoring this developing issue, it can be said that this process is a media monitoring process in normal conditions which is carried out every day by the Public Relations of PTPN X. The following is the flow of the monitoring media stages in normal conditions:

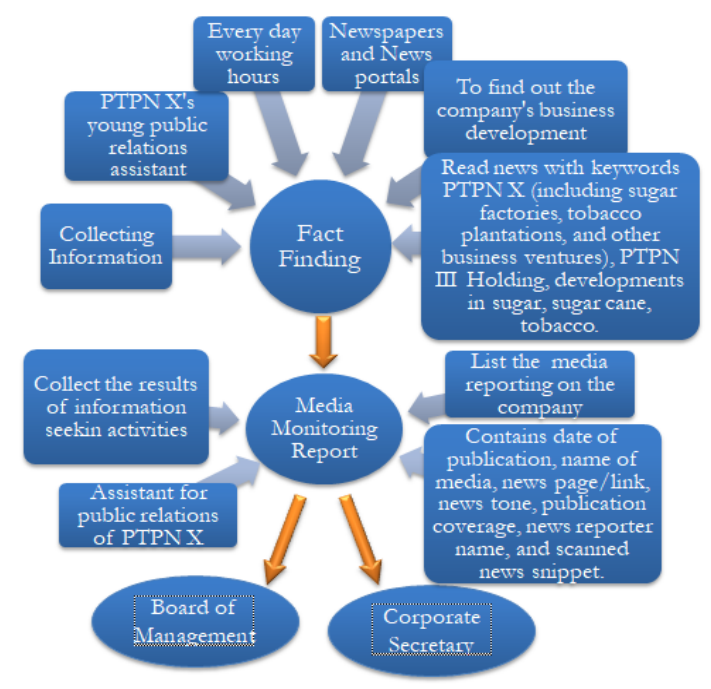

Picture 1. PTPN X Media Monitoring Model in Normal Condition

Source : Researcher

In the period 4 February - 5 August 2019 there was 101 news that was monitored both in printed media (newspapers) and online media (news portals) by PR PTPN X with details as follows:

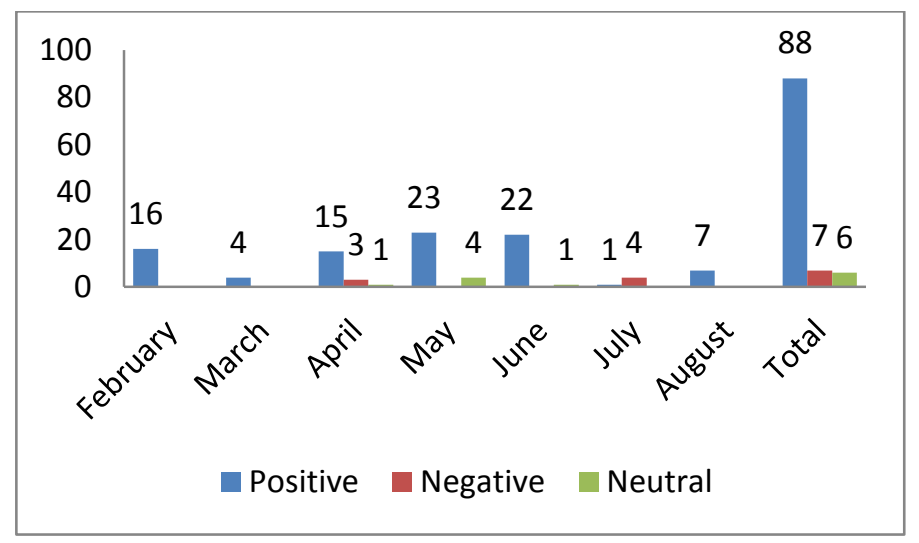

Meanwhile, the focus of the news on 4 February - 5 August 2019 is as follows:

Printed Media (Newspapers)

\begin{tabular}{clcc}
\hline No & \multicolumn{1}{c}{ News Focus } & Frecuency & Percentage \\
\hline $\mathbf{1}$ & Sugar development & 17 & $40,5 \%$ \\
$\mathbf{2}$ & PTPN X program & 17 & $40,5 \%$ \\
$\mathbf{3}$ & Bioethanol energy & 2 & $4,8 \%$ \\
$\mathbf{4}$ & PG Djombang Baru & 1 & $2,4 \%$ \\
& waste fire & & $7,1 \%$ \\
$\mathbf{5}$ & Stakeholder & 3 & $2,4 \%$ \\
& collaboration & 1 & \\
$\mathbf{6}$ & Tobacco & & \\
\hline
\end{tabular}




\begin{tabular}{llcl}
\hline \multirow{7}{7}{} & development & & \\
& PTPN X assets & 1 & $2,4 \%$ \\
& Total & $\mathbf{4 2}$ & $\mathbf{1 0 0 \%}$ \\
\hline
\end{tabular}

\section{Online Media (News Portals)}

\begin{tabular}{clcc}
\hline No & News Focus & Frecuency & Percentage \\
\hline $\mathbf{1}$ & PTPN X program & 52 & $88,14 \%$ \\
$\mathbf{2}$ & The development of & 1 & $1,69 \%$ \\
& PTPN X hospital & & \\
$\mathbf{3}$ & Minister of BUMN Rini & 3 & $5,08 \%$ \\
& Soemarno & & \\
$\mathbf{4}$ & Sugar development & 1 & $1,69 \%$ \\
$\mathbf{5}$ & PG Gempolkrep fire & 2 & $3,39 \%$ \\
& Total & $\mathbf{5 9}$ & $\mathbf{1 0 0} \%$ \\
\hline
\end{tabular}

During the period 4 February - 5 August 2019, the focus of news in PTPN X's media monitoring in printed media (newspapers) was $40.5 \%$ of the most news about the development of sugar and the PTPN X program, with 17 news articles each. The secondlargest coverage was about the company's cooperation with stakeholders at $7.1 \%$ with the number of reports, 3 news articles. And the third-largest was regarding the development of bioethanol energy which is the business of PTPN X, 4.8\% with the number of reports 2 news articles.

Meanwhile, in online media (news portals) the most coverage was discussion of the PTPN X program, which was $88.14 \%$ with 52 articles. The second-largest number of reports was the discussion of BUMN minister Rini Sumarno as much as $5.08 \%$ with the number of articles, 3 news articles. And the third is the news about the PG Gempolkrep waste fire 3.39\% with the number of news articles 2 news articles.

The opinion tone of the news sources on 4 February - 5 August 2019 are as follows:

\section{Newspapers}

\begin{tabular}{lcc}
\hline News Tone & Frequency of the number of news article & Percentage \\
\hline Positive & 48 & $54,5 \%$ \\
Neutral & 35 & $39,8 \%$ \\
Negative & 5 & $5,7 \%$ \\
Total & $\mathbf{8 8}$ & $\mathbf{1 0 0} \%$ \\
\hline
\end{tabular}

News Portals

\begin{tabular}{lcc}
\hline News Tone & Frequency of the number of news article & Percentage \\
\hline Positive & 71 & $95,9 \%$ \\
Neutral & 1 & $1,4 \%$ \\
Negative & 2 & $2,7 \%$ \\
Total & $\mathbf{7 4}$ & $\mathbf{1 0 0} \%$ \\
\hline
\end{tabular}

The opinion tone of news sources in PTPN X monitoring media showed that in printed media (newspapers) more positive tones appeared, at $54.5 \%$ with the total number of articles as many as 48 news articles. Neutral tone at 39.8\%, with 35 news articles, and negative 
opinion tones were recorded at 5.7\% with the number of news articles 5 . While in online media (news portals), positive opinion tones were also recorded more dominating, namely $95.9 \%$ with the number of news articles as much as 71 . The second most was negative opinion tones at $2.7 \%$ with the number of articles as many as 2 articles and the third is neutral opinion tone of $1.4 \%$ with the number of articles as much as 1 newsletter.

\section{Media Monitoring as a form of evaluation of releases distributed to the mass media}

Cutlip, Center \& Broom (2011), states that program evaluation consists of three types, those are preparatory evaluation, implementation evaluation, and impact evaluation. Preparatory evaluation is carried out to assess the quality and adequacy of information collection and strategic planning. An implementation evaluation will record the adequacy of tactics and efforts. Impact evaluation provides feedback on the consequences of the program. ${ }^{19}$ While it is also important to be used as an indicator in analyzing content as part of the evaluation of media monitoring, first, the categorization of media that have high circulation, rating, and influence; second Prominences, such as page numbers or messages in electronic media newsletters and the use of photographs or visuals. Third, Positioning, namely the title, first paragraph designation, prominent designations, or passing designations and 'media share' in the article. Fourth, the size of the article or the length of the radio and TV segment, and the fifth is the use of sources. ${ }^{20}$

In addition to managing issues, PTPN X's media monitoring activities are also used as evaluation material for releases disseminated to the mass media by PTPN X Public Relations for important activities that have been carried out by the company. The implementation process is almost the same as media monitoring activities in managing issues. However, what distinguishes it lies in its function, as an evaluation material for releases distributed to the mass media. Is the release is distributed to the mass media will be the same as the release that was distributed or is there any mass media that still reports news that is in a positive/neutral/negative tone from the release that is distributed. Apart from that, media monitoring of this release is also to measure how much publicity is carried out by the mass media regarding an activity carried out by the company. The more media that report in a positive tone, the better the company's image and reputation will be, and the company's relations in media relations activities carried out by PTPN X Public Relations will be considered successful in fostering good relations with the public.

${ }^{19}$ Cutlip, Scott M. Center, Allen H. Broom, Glen M.Effective Public Relations, ed. ke-9.Terjemahan :Tri Wibowo.Jakarta:Kencana, 2011.

${ }^{20}$ Macnamara and J. R., 'Media Content Analysis: Its Uses, Benefits and Best Practice Methodology', Asia-Pacific Public Relations Journal, 6.1 (2005), 1-34. 


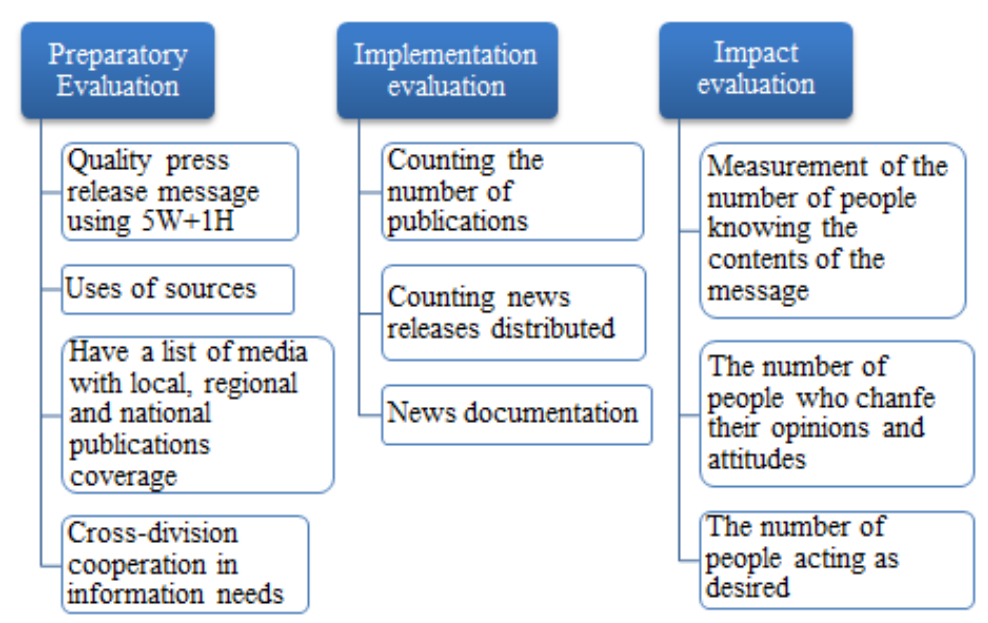

Picture 2. Release Evaluation Model distributed to the Mass Media

Ibid.

In this case, if it is related to the program evaluation theory of Cutlip et al. (2011), PTPN X places program evaluation in the preparatory evaluation and implementation evaluation models. Preparatory evaluation can be seen in the preparation activity of making press release materials that are guided by the quality of the message using the $5 \mathrm{~W}+1 \mathrm{H}$ elements (what, where, when, who, why, and how) according to the criteria usually set by the mass media. In addition, PTPN X has a list of media that has local, regional and national publication coverage as a place to spread messages/information about the programs implemented by PTPN X. PTPN X also collaborates with other departments/divisions such as finance, engineering, human resources, management, and others to complete the information needs in a press release manuscript that will be disseminated to the mass media. The criteria and preparation methods proposed by Cutlip et al. (2011) are firstly the adequacy of background information used to plan programs, secondly assessing the organization and appropriateness of the program as well as message strategy and tactics, the third is message quality and program elements. ${ }^{21}$

While in implementation evaluation, PTPN X Public Relations through media monitoring activities carried out the process of calculating publications in printed media (newspapers) and online media (news portals) through making media monitoring reports that were sent to the company secretary and the management board containing the media that reports about the program implemented by PTPN X and provides criteria in the form of media name, publication date, media coverage, news position, use of positive, neutral and negative tones and the name of the reporter in the report. This is under what was stated by Cutlip et al. (2011), that the implementation evaluation approach is usually to count the number of printed publications; distributed news releases; news placed in the media; readers, viewers, or listeners (potential and actual). Meanwhile, if you look at the criteria and methods in the implementation evaluation, the first is to record the distribution, which is the number of messages distributed. This step is to document all the material and activities produced and

21 Cutlip, Scott M. Center, Allen H. Broom, Glen M.Effective Public Relations, ed. ke-9.Terjemahan :Tri Wibowo.Jakarta:Kencana, 2011. 
the number produced. Second, the number of messages placed in the media affects the target public. Clipping and broadcast are used to measure the portion of news releases and public announcements used by the media. Third, the number of the public who receive program messages; and the fourth is the number of people who pay attention to the message. ${ }^{22}$ In this case, the second, third, and fourth criteria in the implementation method, it appears that the Public Relations of PTPN X has not carried out any measurement of the target public, such as calculating the effect of the number of messages placed in the media on the target public, the number of publics receiving program messages and the number of people who pay attention to the messages. Implementation evaluation can only be seen in the activities of documenting and counting the number of media reporting about PTPN X in both positive and negative tones.

From the explanation above, it can be concluded that PTPN X only carries out two forms of evaluation, which are preparatory evaluation and implementation evaluation. While the ideal evaluation process in the context of PR, PR also needs to carry out impact evaluation which is to measure how far the results stated in the program goals and objectives have been achieved. Impact evaluation at PTPN X has not been carried out, due to several factors: 1) Lack of awareness of PTPN X Public Relations staff regarding the importance of measuring public responses that will affect the relationship between the company and stakeholders; 2) Lack of training for PTPN X Public Relations staff on measuring public response to analyze further settlement steps on a company program.

Impact evaluation in the context of PR is very important to be carried out by a PR / PR worker because it can measure the success of a company program and the sustainability of the company's relationship with its public, as well as knowing the company's position in the eyes of its public. Impact evaluation can be done through public research. Public research is very important because if the program continues while impact measurement through research is not carried out, then the impact on other aspects such as finance and scheduling will be affected. The research results also help and provide a stronger foundation to be used in demonstrating and accounting for the performance of Public Relations to company management in a more concrete manner. ${ }^{23}$ Meanwhile Gozali (2005), states that performance measurement through evaluation of communication programs can be used as a reference for organizations to determine whether the program goals and objectives have been achieved or not. $^{24}$

\section{Media Monitoring when a News Crisis Occurs}

Unverified news will always surround the company/organization. Fake news will also spread quickly and can threaten the organization. Especially in today's era, the process of spreading information is fast because of the internet and this will make it easier for the media to raise the news. The truth of information is often put aside to raise the rating of a media.

${ }^{22}$ Ibid.

${ }^{23}$ Ike Devi Sulistyaningtyas, 'Riset Sebagai Ujung Tombak Keberhasilan Program Public Relations', Jurnal ILMU KOMUNIKASI, 7.2 (2013) < https://doi.org/10.24002/jik.v7i2.190>.

${ }^{24}$ Muntadliroh, 'Evaluasi Program Komunikasi Pemerintah Berdasarkan The Pyramid Model Of Public Relations Research (Studi Kasus Program Kantong Plastik Berbayar Kementerian Lingkungan Hidup Dan Kehutanan Tahun 2016)', Jurnal PIKOM (Penelitian Komunikasi Dan Pembangunan), 21.1 (2020), 15-26. 
The result of negative news will have an impact on reputation which will lead to a crisis in a company.

When PTPN X is hit by a problem in media coverage, both in the form of news that is negative, incorrect and errors in writing the news by the media, PTPN X Public Relations takes the following actions:

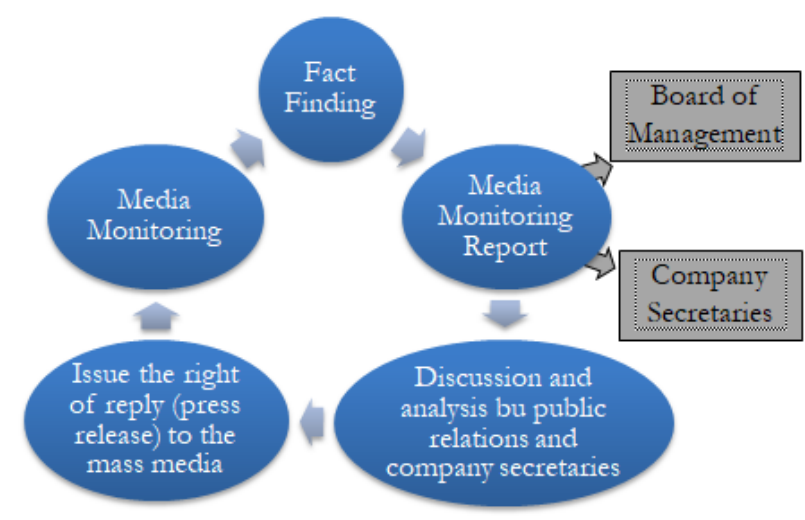

Picture 3. Media Monitoring Model during the News Crisis

Ibid.

The process carried out by the Public Relations of PTPN X in dealing with problems related to media coverage that can threaten the company is, first by carrying out a fact-finding process on problems related to how to monitor news in printed media (newspapers) and online media (news portals) following the steps described in the media monitoring process section. In this process, the fact-finding of the news is more focused on related problems. After the data and facts have been deemed sufficient, PTPN X Public Relations then makes a media monitoring report in which there is news on the related problems complete with the date, media name, news page/link, news tone, and the name of the reporter/journalist who wrote the news. The next step is the media monitoring report, which is sent to the company secretary and the PTPN X Board of Management. Public Relations of PTPN X together with the company secretary conducted an analysis and discussion related to the plan and its followup in dealing with circulating news. If the news is threatening the company, the PR together with the PTPN X company secretary conducts a right of reply process in the form of a statement by sending a press release to the mass media to counter any developing news/issues. The final step is to re-monitor the media if the release has been distributed, whether the media will report such as the release sent or publish news with a different point of view to whether the media develops its reporting case, PTPN X Public Relations conducts media monitoring again until the problem has been resolved well.

In this case, PTPN $\mathrm{X}$ is seen carrying out issue management activities by controlling the environment in the form of monitoring the mass media by searching for data and facts related to the news circulating. This process is an effort to identify the warning signs (signal detection) before formulating preventive strategic steps (prevention). As suggested by Mitroff (2001), which divides five crisis management models, signal detection, which is an effort to identify warning signs and formulate preventive strategies. At this stage, the success of handling the crisis quickly is determined. This stage is also known as the pre-crisis stage, in 
which an issue management process occurs, that is monitoring the environment. Second, probing \& prevention, by actively seeking and reducing risk factors. Third, damage containment, the stage when a crisis occurs and trying to prevent it from getting bigger. Fourth, recovery is an attempt to return to normal conditions. The fifth is learning, organizations and the public examine all the efforts made in crisis management and make it a learning process. ${ }^{25}$ Besides, collecting these facts is also to prepare a statement to the public. On the other hand, the PR of PTPN X is seen as the gatekeeper (boundary spanners). Boundary spanners are someone who regularly interacts with the organizational environment, collects, selects information that is submitted to the environment, both external and internal, and otherwise processes information that comes from the surrounding environment to be conveyed to decision-makers within the company. ${ }^{26}$

Meanwhile, when a crisis is ongoing, the things that must be done are first gathering facts, having a communication team, contacting the mass media, press conferences, not closing information, being careful in conveying information, communicating reputation, uniting the voice, empathetic communication and opening communication channels. ${ }^{27}$ In the process of handling the news crisis, PTPN X has a crisis communication team consisting of the president director, company secretary, and Public Relations of PTPN X. The president director usually becomes a spokesperson in the press release that will be distributed. Meanwhile, the company secretary is in charge of formulating steps to be taken as well as being a communicator along with Public Relations, and Public Relations implementing the planned strategy and executing the formulated plan by creating and distributing press releases. Public Relations of PTPN X were also seen contacting the mass media and opening information channels under the principles of openness and two-way communication to get feedback from the public. In this case, PTPN X Public Relations also opens mass media communication channels, by providing information to printed media journalists and online media by issuing press releases in which there is official information from the company complete with contact persons, which are company secretaries who handle problems related to company news.

Fink (2002), states that to determine a communicator, it must first be seen from its quality. Referring to Lawrence G. Foster (without year), there are two important qualities inherent in the crisis communicator: 1) The communicator must have direct access to the main authority in the organization; 2) Does the communicator have the authority to design the overall flow and content of information. ${ }^{28}$ The position of company secretary here is a person who has direct access and has full authority to convey information to the company's management. The company secretary is directly under the President Director in the company's organizational structure. In other words, the company secretary is the right hand of the

${ }^{25}$ Ruslan, Rosady. Manajemen Public Relations \& Media Komunikasi:Konsep dan Aplikasi.Jakarta:Rajawali Pers, 2012.

26 Suharyanti and Achmad Hidayat Sutawidjaya, 'Analisis Krisis Pada Organisasi Berdasarkan Model Anatomi Krisis Dan', Journal Communication Spectrum, 2.2 (2012), 165-85.

${ }^{27}$ Kriyantono, Rachmad.Public Relations, Issue, \& Crisis Management:Pendekatan Critical Public Relations, Etnografi Kritis, \& Kualitatif:Mengenal Krisis: Jakarta:PRENANDAMEDIA GROUP, 2015.

28 Puspitasari.Komunikasi Krisis:Strategi Mengelola dan Memenangkan Citra di Mata Publik:Anatomi Krisis:Jakarta:Libri, 2016. 
president director in controlling company problems, including in the news and public relations is part of the company secretary.

\section{CONCLUSION}

Based on the data findings that have been described above, the media monitoring model in the PR of a State-Owned Enterprise (BUMN) study at PT Perkebunan Nusantara X can be concluded that first, the media monitoring process carried out by the PR of PT Perkebunan Nusantara X is in the PR model of collaboration level industry 1.0 and 2.0. Where the collaboration between printed media and online media (news portals) as a source of information is implemented by the Public Relations of PTPN X in the process of external media monitoring. The work of monitoring the printed media (newspapers) at PTPN X is still carried out traditionally, by manually monitoring the media by reading the newspaper every day. In addition, the stages carried out are planning, implementation, and evaluation which indicates that the Public Relations of PTPN X is carrying out management functions.

Second, the media monitoring model in normal conditions is to find out which issues are currently hotly discussed by the public, PTPN X Public Relations conducts fact/information searches regarding matters relating to the company through newspapers and news portals to obtain information and find out about the company's business development among the public. Public Relations of PTPN X, in this case, acts as a manager and communication technician. The manager looks active in looking for facts and helps superiors in defining problems and this activity is contained in a media monitoring report which is then reported to the company secretary and management. Meanwhile, communication technicians are seen in the form of relationships with mass media such as subscribing to newspapers every day.

Third, media monitoring is a form of evaluation of releases distributed to the mass media. In this process, PTPN X applies a planning evaluation and implementation evaluation model. Planning evaluation can be seen in the process of making a press release that considers the quality of the message content by applying the $5 \mathrm{~W}+1 \mathrm{H}$ principle (what, where, when, why, who, and how); coordinate with various cross-divisions for the comprehensiveness of the information in the release; use of important sources, such as management; have a list of local, regional and national media in the process of spreading the release. Meanwhile, the implementation evaluation can be seen in the counting of the number of news published in the mass media which is contained in the monitoring media reports.

Fourth, when a news crisis occurs, the media monitoring model that is applied is slightly different from normal conditions, when the news crisis is more focused on related problems, it is quickly responded by starting fact-finding as soon as possible, then taking immediate action after analysis and discussion by Public Relations and the company secretary by issuing a press release as part of the right of reply to the mass media. 


\section{REFERENCES}

Gunawan, Aditya Ilham, and Renata Anisa, 'Kegiatan Media Monitoring Humas Pemerintah Kota Cimahi', Ekspresi Dan Persepsi: Jurnal Ilmu Komunikasi, 3.2 (2020), 122 $<$ https://doi.org/10.33822/jep.v3i2.1758>

Kriyantono, Rachmat, 'Peran Manajerial Dan Teknisi Humas Lembaga Pemerintah Dan Swasta', Aristo, 6.1 (2018), 1 <https://doi.org/10.24269/ars.v6i1.760>

Macnamara, and J. R., 'Media Content Analysis: Its Uses, Benefits and Best Practice Methodology', Asia-Pacific Public Relations Journal, 6.1 (2005), 1-34

Maulida, Mia Rizqi, and Tresna Wiwitan, 'Aktivitas Media Monitoring Biro Humas Kementerian Perdagangan Republik Indonesia’, 164-69

Muntadliroh, 'Evaluasi Program Komunikasi Pemerintah Berdasarkan The Pyramid Model Of Public Relations Research (Studi Kasus Program Kantong Plastik Berbayar Kementerian Lingkungan Hidup Dan Kehutanan Tahun 2016)', Jurnal PIKOM (Penelitian Komunikasi Dan Pembangunan), 21.1 (2020), 15-26

Prajarto, Nunung, 'Efektivitas Publisitas: Menilai Reputasi Institusi', Jurnal Ilmu Komunikasi, 6.2 (2008), 78-84

Suharyanti, and Achmad Hidayat Sutawidjaya, 'Analisis Krisis Pada Organisasi Berdasarkan Model Anatomi Krisis Dan', Journal Communication Spectrum, 2.2 (2012), 165-85

Sulistyaningtyas, Ike Devi, 'Riset Sebagai Ujung Tombak Keberhasilan Program Public $\begin{array}{llll}\text { Relations', Jurnal ILMU } & \text { KOMUNIKASI, } & 7.2\end{array}$ $<$ https://doi.org/10.24002/jik.v7i2.190>

Arief, Nurlaela.Public Relations In The Era of Artificial Intelligence: Bagaimana Big Data dan AI Merevolusi Dunia PR.Bandung:Simbiosa Rekatama Media, 2019.

Cutlip, Scott M. Center, Allen H. Broom, Glen M.Effective Public Relations, ed. ke9.Terjemahan :Tri Wibowo.Jakarta:Kencana, 2011.

Darmastuti, Rini.Media Relations:Konsep, Strategi \& Aplikasi.Yogyakarta:ANDI OFFSET,2012.

Kriyantono, Rachmad.Public Relations, Issue, \& Crisis Management:Pendekatan Critical Public Relations, Etnografi Kritis, \& Kualitatif:Mengenal Krisis: Jakarta:PRENANDAMEDIA GROUP, 2015.

Machmud, Muslimin.Tuntutan Penulisan Tugas Akhir Berdasarkan Prinsip Dasar Penelitian Ilmiah.Malang:Penerbit Selaras, 2016.

Makmur, Riniwaty.Media Relations di Balik Layar:Praktik, Tips dan Teori.Jakarta:PT Kompas Media Nusantara, 2019.

Prayudi.Penulisan Naskah Public Relations.Yogyakarta:ANDI OFFSET,2007.

Puspitasari.Komunikasi Krisis:Strategi Mengelola dan Memenangkan Citra di Mata Publik:Anatomi Krisis:Jakarta:Libri, 2016.

Ruslan, Rosady. Manajemen Public Relations \& Media Komunikasi:Konsep dan Aplikasi.Jakarta:Rajawali Pers, 2012.

ptpn10.co.id.(2021, 24 Februari). Sejarah Perusahaan. Diakses pada 24 Februari 2021, dari http://ptpn10.co.id/page/profil\#sejarah. 